\title{
THE EFFECT OF GABIONS ON THE QUALITY OF A STREAM HABITAT
}

\author{
MAJOROŠOVÁ, M. ${ }^{1}$ - ŠTEFUNKOVÁ, Z. ${ }^{1}$ - BELČÁKOVÁ, I. ${ }^{2}$ - ŠKRINÁR, A. ${ }^{{ }^{*}}$ \\ MACURA, V. \\ ${ }^{I}$ Faculty of Civil Engineering, Slovak University of Technology in Bratislava \\ Radlinského 11, 81005 Bratislava, Slovakia \\ (phone: 421-2-5927-4471; fax: +421-2-5296-7027) \\ ${ }^{2}$ Faculty of Ecology and Environmental Sciences, Technical University in Zvolen \\ T. G. Masaryka 24, 96053 Zvolen, Slovakia \\ (phone: +421-455-206-492; fax: +421-455-206-279) \\ *Corresponding author \\ e-mail: andrej.skrinar@stuba.sk; phone: 421-2-5927-4617; fax: +421-2-5292-3575 \\ (Received 12 $2^{\text {th }}$ Mar 2018; accepted 21 ${ }^{\text {st }}$ May 2018)
}

\begin{abstract}
Research on the effect of gabions (wire mattresses filled by stones) on stream biota was conducted on the regulated and natural reference reaches of the Oščadnica stream in northern Slovakia. The fish community reacts sensitively not only to overall sets of changes but also to the shape and material of a riverbed. Therefore, the assessment of the impact of the gabions on the stream biota was realized by the bioindication of the ichthyofauna. Based on a comparison of the quantitative indicators in the regulated and natural reference reaches of the Oščadnica stream, we can say that gabions do not have any negative effects on the ichthyofauna, which is mainly represented by brown trout. Brown trout is the species that reacts most sensitively to morphological stream changes. The results of the research show that gabions do not have any negative effects on the stream biota.
\end{abstract}

Keywords: bioindication, ichthyofauna, river regulation, armouring of the river channel, abundance, ichthyomass

\section{Introduction}

River regulation changes a river's basic morphological and flow characteristics, for example, by alternating riffle zones with calm pool areas and introducing variable riparian borders with a wide range of cover places for fish. This type of activity has a negative impact on river biota and results in decreased biodiversity (Cianfrani et al., 2009; Palmer et al., 2010). Modifications resulting from regulations are very noticeable in assessments of the availability of specific habitats that are necessary for a river's restoration (Mažeika et al., 2006). It has been shown that the negative impacts of river regulation are mainly restricted to a river's upper reaches or rhitral streams (Macura, 2012). The variability of a riverbed decreases in the upper part of a stream, which has a significant impact on the ichthyofauna. Therefore, any morphological changes are reflected by the fish (Macura et al., 2012).

The research shows that freshwater fish are good indicators of morphological changes in the river channel and biotic integrity in freshwater ecosystems (Pont et al., 2006, Cheek et al., 2016, Roni et al., 2014, Schmutz and Jungwirth, 1999). They also respond sensitively to changes in temperature and flow (Avery-Gomm et al., 2014, Schlosser, 1987, 1990; Cowx and Welcomme, 1998). Due to their longevity, mobility and sensitivity to biotope changes, they are suitable for assessing the ecological river 
integrity (Keeley et al., 2015, Aarts and Nienhuis, 2003, Chovanec et al., 2003, Welcomme et al., 2006).

The Water Framework Directive (2000/60/EU) requires information about morphological changes and other characteristics of the quality of a stream that affect the presence of macrophytes and macroinvertebrates (Artemiadou et al., 2005; Friberg et al., 2005).

A river restoration scheme that preserves the high variability of a riverbed does not have any negative impact on an overall ecosystem. The design parameters of covers, pools and other structures that create a variable morphology in a regulated channel are therefore important components of restoration proposals of rivers (Koščo et al., 2010) and water reservoirs (Augustinková et al., 2017). Biological and hydrological relations have been studied in many streams, and authors have drawn attention to specific flow patterns that are specific to individual regions. However, these relations are better described by biological responses to alterations in flow regimes (Snelder and Lamouroux, 2010).

Therefore, it is necessary to focus on the factors that affect the living conditions of aquatic organisms and their life processes. Therefore, fish are suitable bioindicators for a water environment because their lives are closely connected to their environment. Individual species always occupy a certain kind of habitat, so that each change in the environment can cause changes in its fish community. Species that are able to adapt can survive; others recede into more suitable conditions or are completely eliminated. Other species that can survive in these conditions come to that location, which changes not only the whole original fish community but also the ecological nature of the flow. The fish community reacts sensitively not only to a whole set of changes but also to the shape of and the material constituting the riverbed.

Intensive discussions are ongoing among water managers, ichthyologists and hydrobiologists. Nowadays, these specialists believe that the success or failure of any restoration project depends on understanding of river biotopes (Zhang et al., 2016) and continuous stream monitoring. The aim of current research is to quantify the design characteristics of appropriate habitats for river restorations (Döll et al., 2010; Pastuchová et al., 2008). Taking this trend into account, the results in this article are focused on the impact of the objectification of gabions on the aquatic habitats of streams.

\section{The characteristics of gabions}

The basic philosophy of a gabion's structure is its fusion with a natural environment. After decades, the whole gabion's construction is overgrown by vegetation and is thereby perfectly stabilized. The system is ecological; the materials used have a natural character, except for the use of wires that are covered by a PVC protective layer. This type of gabion is only used when the wiring construction is expected to have a long life and is located in an aggressive environment. Based on the type of construction for which the structure is designed, several basic types of products, such as baskets, mattresses and sacks, are available. These elements can be combined. To stabilize a slope, a combination of a basket with a rod that forms a mesh of different lengths is also often used.

An important area in gabion constructions is their use in water management structures. It is even possible to say that we find gabion constructions the most 
important constructions in the field of water management structures. As in other types of constructions, different systems and materials can be used. In water management structures, wire mattresses are the most suitable construction elements due to their elasticity. Because a flexible construction can copy a terrain and carry large deformations without any destruction, wire mattresses can be recommended for fragmented riverbanks in river restorations.

\section{Materials and methods}

The Oščadnica stream in northern Slovakia (Fig. 1), where the two reference reaches were chosen, was selected to determine the impact of wire mattresses in a regulated stream channel. The natural reference reach $\left(49.4193^{\circ} \mathrm{N} 18.8417^{\circ} \mathrm{E}\right)$ is $150 \mathrm{~m}$ above the regulated stream channel $\left(49.4198^{\circ} \mathrm{N} 18.8388^{\circ} \mathrm{E}\right)$. The stream channel is structured, and the riverbanks are stabilized by the root system of the riverbank vegetation (Fig. 2).

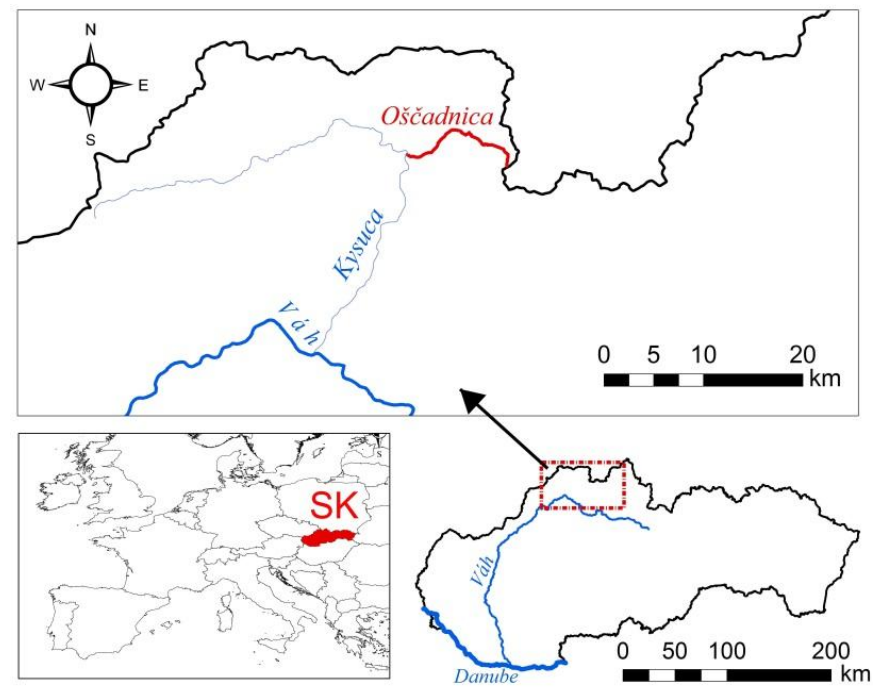

Figure 1. Location of the Oščadnica stream within Europe

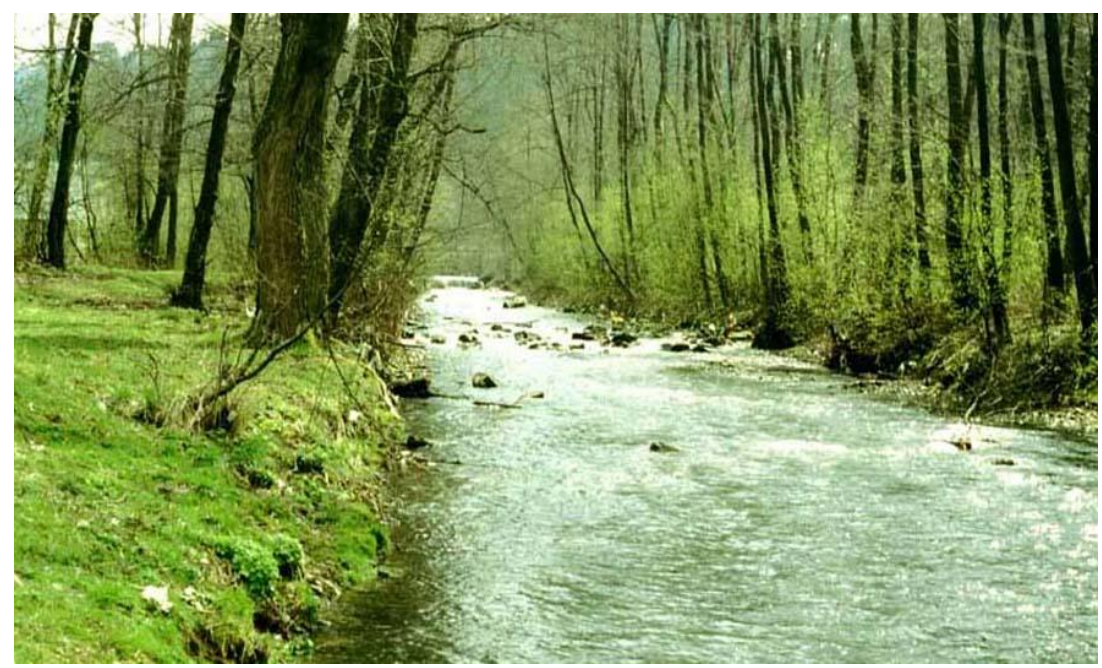

Figure 2. Natural reference reach of the Oščadnica stream 
In the regulated reference reach, the stream channel has a simple trapeziodal profile with slopes on a gradient of 1:1.5. The slopes and the base are stabilised by wire mattresses. The reference reach lacks riverbank vegetation (Fig. 3).

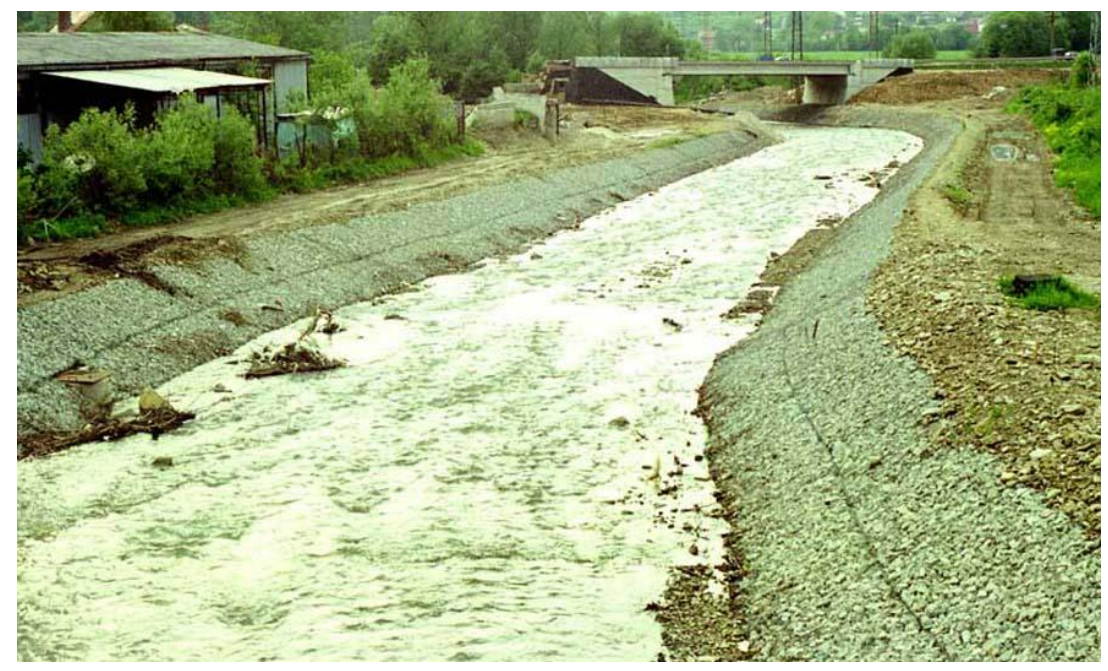

Figure 3. Regulated reference reach of the Oščadnica stream; the riverbanks are stabilized by wire mattresses

\section{The water quality}

The data about the water quality in the Oščadnica stream were taken from the hydroecological projects of the Váh catchment. The oxygen content was determined by direct measurements by an oxygen searcher (Hana Instruments) during the ichthyological research. The saturation of the water by oxygen ranged from $95.2 \%$ to $98.8 \%$.

\section{Topographic measurements in the reference reaches}

The topography of the reference reaches is represented by cross sections that are related to the polygonal traction. The polygonal traction is created by points located between 20 - $25 \mathrm{~m}$ apart. The cross section was measured by nivelation from each point. The polygonal traction points were fixed with wooden pins. Properly measured polygonal traction allows for the changing of any fixed points in case of their damage. Longitudinal and cross sections were implemented for the hydraulical model.

\section{Ichthyological research}

The research on the Oščadnica stream was realised five times between 2015 and 2016. The selected reference reaches of the stream were covered by $10 \times 10 \mathrm{~mm}$ mesh barriers at both ends after hydrometric measurements. The fish were pursued by an electrical aggregate. After the fish were caught, they were placed in a relay located below the lower barrier in the stream and outside the electric field. In each reference reach obstructed by mesh, three hunts were undertaken at an average interval of 45 minutes. After each hunt, the fish were counted, measured, weighed and released back to the stream below the mesh. 
The abundance was evaluated from the measured data, according to the Leslie and Davis method (1939). These values, in combination with the average weight of each species, were used to calculate the biomass of each species and the total ichthyomass. „Abundance" refers to the frequency rate of each species, whereas the biomass is its total weight. The total abundance means the entire frequency rate of all the individual species in the community in the selected stream, and the ichthyomass means the total weight of the community. The abundance, biomass and ichthyomass values are presented per hectare of the water surface.

"Occurrence constancy" is evaluated according to the presence of individual species in a given reference reach depending on the time. This "occurrence constancy" expresses the persistence of the generic composition of the ichtyocenosis.

The relevant calculations are:

$$
K=\frac{n_{i}}{a}
$$

where $K$ is the "Occurrence constancy", $n_{i}$ is the amount of samplings of the occurrence of the species $i$, and $s$ is the number of all the samplings. The occurrence constancy is expressed in the following categories:

I uncommon species: 0-20\%

II rarely occurring species: $20-40 \%$

III species often occurring: $40-60 \%$

IV species predominantly occurring: $60-80 \%$

V species almost always occurring: $80-100 \%$

Other characteristics of the ichthyofauna are shown by the species diversity index and equitability index. The diversity index represents the ratio of the number of species and the number of individuals in the population. The diversity index is a structurally quantitative expression of the characteristics of each community, in this case, ichthyocenoses. The relevant calculation is:

$$
H^{\prime}=\sum_{i=1}^{s}\left(\frac{n_{i}}{N}\right) \cdot \ln \left(\frac{n_{i}}{N}\right)
$$

where $S=$ total number of species, $n_{i}=$ number of individuals for " $i$ " species, and $N$ $=$ total number of individuals of all the species.

Equitability (equanimity) relates to diversity and expresses the relative distribution of all the individuals in the community of the species present. The relevant calculations are:

$$
K=\frac{H^{r}}{\ln S}
$$

where $H^{\prime}=$ diversity index, and $S=$ the total number of species detected.

\section{Schedule of the field measurements}

From the perspective of the determining the impact of the stream regulation, the impact of climate change or the conservation of fishery resources, it is important to focus on the summer period (Carlson et al., 2015, Murchie et al., 2008). Summer period at the minimum discharge can be considered as a design condition, because it creates 
the highest load on the biota of the stream. High discharges do not have any significant negative impact on the biota of the stream. Hence, the dates of ichthyological, topographic and hydrological measurements were scheduled during the summer period at low water levels. To accentuate the impact of higher temperatures, ichthyological measurements have started at 11 am and ended after $4 \mathrm{pm}$. After all, the discharge was determined by hydrometry and the water level in the individual cross sections was marked. The topography of the riverbed was always measured the following day, after ichthyological and hydrometric measurements. Specific dates for ichthyological and hydrometric surveys were: 4.6.2015, 27.10.2015, 12.6.2016, 24.7.2016 and 2.9.2016.

\section{Results}

In the natural reference reach of the Oščadnica stream, there are demonstrably higher abundance values but small differences in the biomass (Fig. 4 and Table 1). From the data, it is clear that fewer fish were present in the regulated stream reference reach but that their weight was higher. The hydrobiological research also confirmed that the wire mattresses did not have any negative impact on the macrozoobenthos. An evaluation of the macrozoobenthos on both reference reaches indicated that no significant difference was found in the structure of the species and in the amount of the bottom fauna in the regulated and natural reference reaches. The amount of organisms was only lower in the sampling in 2015 in the regulated reference reach, but the species diversity was higher in the regulated reference reach. There were no differences in the number of taxa found (the measurements were taken twice, i.e., in May and September).

The results obtained indicate that even in a prismatic stream channel that is not suitable for fish, there are the same ichtyomass and macrozoobenthos. This confirms the assumption that wire mattresses have a similar influence on the biota as rockfill or as a natural riverbank.

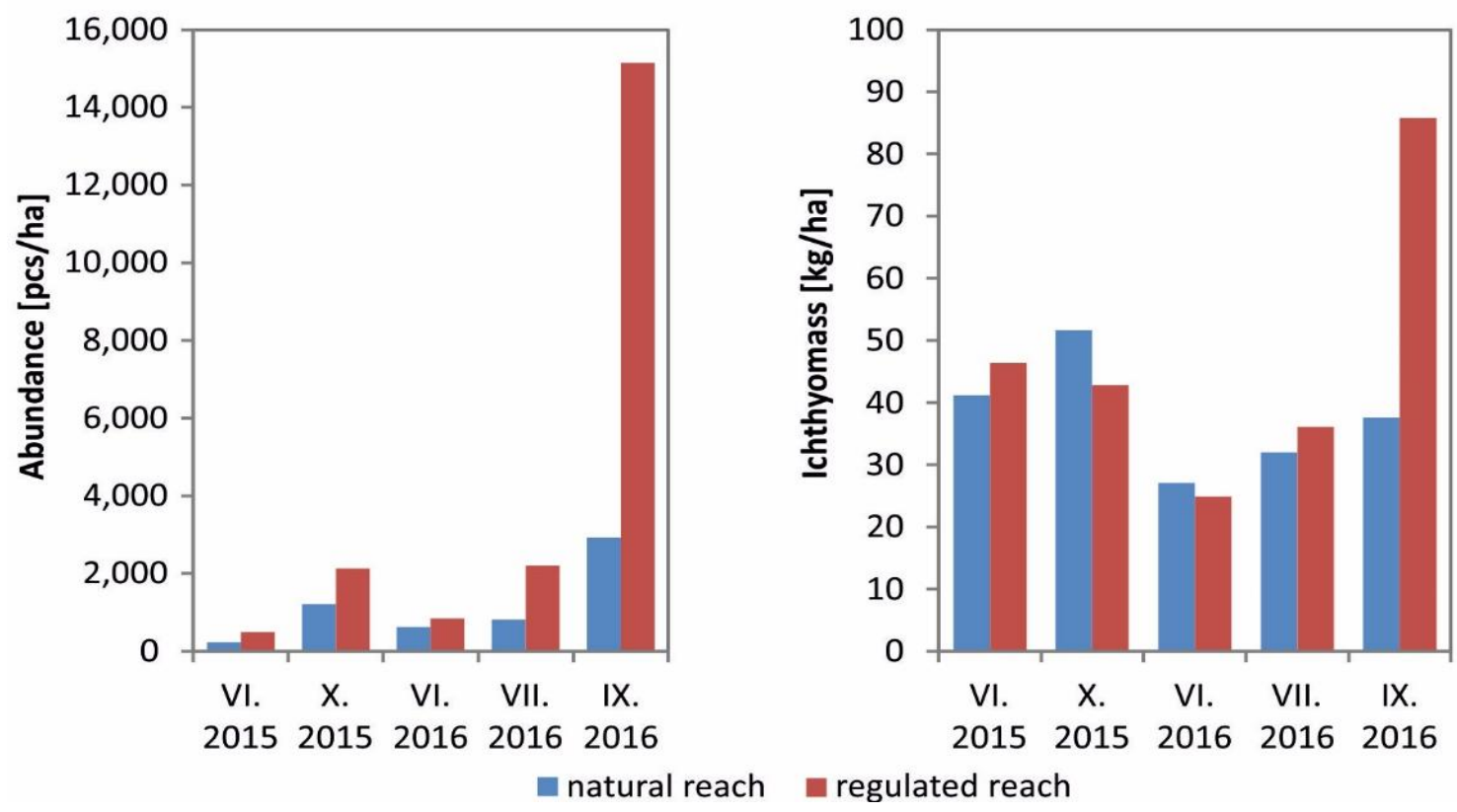

Figure 4. Abundance (pcs per $\mathrm{ha}^{-1}$ ), ichtyomass $\left(\mathrm{kg} \mathrm{per}^{-1} \mathrm{a}^{-1}\right)$ in the regulated and natural parts of the Ořcadnica stream 
Table 1. The abundance (pieces per ha $\mathrm{a}^{-1}$ ), biomass ( $\left.\mathrm{kg} \mathrm{per} \mathrm{ha}^{-1}\right)$, and the average individual weight $\left({\mathrm{g} . \mathrm{ind}^{-1}}^{-1}\right)$ of the fish species detected in the natural and regulated reference reaches of the Ořčadnica stream between 2015 and 2016

\begin{tabular}{|c|c|c|c|c|c|c|c|}
\hline \multirow[t]{2}{*}{ Species } & \multirow[t]{2}{*}{ Date } & \multicolumn{3}{|c|}{$\begin{array}{c}\text { Natural stream } \\
\left(49.4193^{\circ} \mathrm{N} 18.8417^{\circ} \mathrm{E}\right)\end{array}$} & \multicolumn{3}{|c|}{$\begin{array}{c}\text { Regulated stream } \\
\left(49.4198^{\circ} \mathrm{N} 18.8388^{\circ} \mathrm{E}\right)\end{array}$} \\
\hline & & pcs.ha $^{-1}$ & kg.hat ${ }^{-1}$ & g.ind $^{-1}$ & pcs.ha $^{-1}$ & kg.ha ${ }^{-1}$ & g.ind ${ }^{-1}$ \\
\hline \multirow[t]{5}{*}{$\overline{\text { BT }}$} & 4.6 .2015 & 117 & 34.6 & 55.4 & 164 & 35.4 & 46.8 \\
\hline & 27.10 .2015 & 860 & 44.5 & 52.3 & 35 & 0.7 & 39 \\
\hline & 12.6.2016 & 366 & 20.4 & 58.4 & 283 & 18.5 & 61.9 \\
\hline & 24.7.2016 & 699 & 28.2 & 37.6 & 407 & 21 & 55.2 \\
\hline & 2.9.2016 & 1665 & 31.4 & 27.1 & 814 & 22.8 & 26.3 \\
\hline \multirow[t]{5}{*}{ EM } & 4.6 .2015 & 1 & 0.04 & 8 & 186 & 3.7 & 4.3 \\
\hline & 27.10 .2015 & & & & 952 & 11.5 & 14.2 \\
\hline & 12.6 .2016 & & & & 308 & 3 & 9.1 \\
\hline & 24.7 .2016 & & & & 1245 & 5.7 & 4.8 \\
\hline & 2.9.2016 & & & & 11788 & 43.7 & 3.5 \\
\hline \multirow[t]{5}{*}{$\overline{\mathrm{AB}}$} & 4.6 .2015 & 92 & 6.5 & 13.4 & 18 & 0.6 & 7.6 \\
\hline & 27.10 .2015 & 356 & 7.2 & 20.5 & 35 & 0.7 & 10.2 \\
\hline & 12.6 .2016 & 250 & 6.5 & 27.7 & 60 & 1 & 15 \\
\hline & 24.7 .2016 & 114 & 3.8 & 30.7 & 37 & 0.9 & 26.7 \\
\hline & 2.9.2016 & 1262 & 6.2 & 7.1 & 1159 & 5.2 & 4.3 \\
\hline \multirow[t]{5}{*}{ SL } & 4.6 .2015 & 3 & 0.1 & 8.5 & 123 & 5.1 & 9 \\
\hline & 27.10 .2015 & & & & 335 & 3.6 & 12.8 \\
\hline & 12.6 .2016 & 8 & 0.1 & 13 & 197 & 2.4 & 11 \\
\hline & 24.7.2016 & & & & 469 & 5.1 & 11.7 \\
\hline & 2.9.2016 & & & & 1381 & 14.1 & 9.6 \\
\hline $\mathrm{CH}$ & 27.10 .2015 & & & & 18 & 1.1 & 70 \\
\hline \multirow[t]{2}{*}{$\mathrm{G}$} & 27.10 .2015 & & & & 9 & 0.2 & 25 \\
\hline & 24.7 .2016 & & & & 49 & 3.4 & 74.7 \\
\hline \multirow[t]{5}{*}{$\Sigma$} & 4.6 .2015 & 213 & 41.24 & 85.3 & 491 & 44.8 & 67.7 \\
\hline & 27.10 .2015 & 1216 & 51.7 & 72.8 & 1384 & 17.8 & 171.2 \\
\hline & 12.6 .2016 & 624 & 27 & 99.1 & 897 & 28.3 & 171.7 \\
\hline & 24.7 .2016 & 813 & 32 & 68.3 & 2158 & 32.7 & 98.4 \\
\hline & 2.9 .2016 & 2927 & 37.6 & 34.2 & 15142 & 85.8 & 43.7 \\
\hline
\end{tabular}

Explanations: $\mathrm{BT}=$ brown trout, $\mathrm{EM}=$ Eurasian minnow, $\mathrm{AB}=$ Alpine bullhead, $\mathrm{SL}=$ stone loach, $\mathrm{CH}=$ chub, $\mathrm{G}=$ grayling

There are six species of fish (Table 2) in the monitored reference reaches of the Oščadnica stream. While all six species were present in the regulated reference reach, only four species were detected in the natural reference reach. Grayling and chub are not found in this reference reach. The "constantly occurring" species in both reference reaches are Eurasian minnow, brown trout and Alpine bullhead; the regulated reference reach also contains stone loach. The grayling and chub in this reference reach belong to category I, uncommon species. The stone loach in the regulated reference reach belongs to category II, species that rarely occur.

The state of these indexes of the diversity and equitability of the species in the regulated reference reach is statistically higher than in the natural reference reach (Table 3). 
Table 2. Composition of the species of ichthyofauna in the monitored reference reaches of the Oščadnica stream between 2015 and 2016

\begin{tabular}{|c|c|c|}
\hline Family / Species & Natural stream & Regulated stream \\
\hline $\begin{array}{c}\text { Cyprinidae } \\
\text { Eurasian minnow - Phoxinus phoxinus } \\
\text { Chub - Leuciscus cephalus }\end{array}$ & $\begin{array}{l}+ \\
-\end{array}$ & $\begin{array}{l}+ \\
+\end{array}$ \\
\hline $\begin{array}{c}\text { Balitoridae } \\
\text { Stone loach - Barbatula barbatula }\end{array}$ & + & + \\
\hline $\begin{array}{c}\text { Salmonidae } \\
\text { brown trout - Salmo trutta m. fario }\end{array}$ & + & + \\
\hline $\begin{array}{c}\text { Thymallidae } \\
\text { Grayling - Thymallus thymallus }\end{array}$ & - & + \\
\hline $\begin{array}{c}\text { Cottidae } \\
\text { Alpine bullhead - Cottus poecilopus }\end{array}$ & + & + \\
\hline Total frequency rate number of species & 4 & 6 \\
\hline
\end{tabular}

Table 3. The summarized statistical data on the diversity index $\left(H^{\prime}\right)$ and equitability $\left(E^{\prime}\right)$ in the monitored reference reaches of the Oščadnica stream between 2015 and 2016

\begin{tabular}{|c|c|c|c|c|}
\hline \multirow{3}{*}{ Parameter } & \multicolumn{2}{|c|}{ Natural ref. reach (1) } & \multicolumn{2}{|c|}{ Regulated ref. reach (2) } \\
\hline & \multicolumn{4}{|c|}{$H^{\prime}$} \\
\hline & Spring (1a) & Autumn (1b) & Spring (2a) & Autumn $(2 b)$ \\
\hline$\theta$ & 0.92 & 0.9 & 1.74 & 1.38 \\
\hline$s$ & 0.29 & 0.12 & 0.12 & 0.39 \\
\hline$v$ & 31.43 & 13.28 & 6.65 & 28.08 \\
\hline$n$ & 3 & 2 & 3 & 2 \\
\hline$\theta$ & \multicolumn{2}{|c|}{0.92} & \multicolumn{2}{|c|}{1.6} \\
\hline$s$ & \multicolumn{2}{|c|}{0.21} & \multicolumn{2}{|c|}{0.29} \\
\hline$v$ & \multicolumn{2}{|c|}{23.37} & \multicolumn{2}{|c|}{18.01} \\
\hline$n$ & \multicolumn{2}{|c|}{5} & \multicolumn{2}{|c|}{5} \\
\hline$t(1 \mathrm{a}, 1 \mathrm{~b})$ & \multicolumn{4}{|c|}{$454 * *$} \\
\hline$t(1 \mathrm{a}, 2 \mathrm{a})$ & \multirow{2}{*}{\multicolumn{4}{|c|}{$\begin{array}{c}4.54^{* * *} \\
-\end{array}$}} \\
\hline$t(2 \mathrm{a}, 2 \mathrm{~b})$ & & & & \\
\hline$t(1 \mathrm{~b}, 2 \mathrm{~b})$ & \multicolumn{4}{|c|}{-} \\
\hline \multirow[t]{3}{*}{$t(1,2)$} & \multicolumn{4}{|c|}{$4.23 * *$} \\
\hline & \multicolumn{4}{|c|}{$E^{\prime}$} \\
\hline & Spring (1a) & Autumn (1b) & Spring (2a) & Autumn (2b) \\
\hline$\theta$ & 2.01 & 3 & 2.63 & 1.98 \\
\hline$s$ & 0.19 & 0.4 & 0.36 & 0.2 \\
\hline$v$ & 9.58 & 13.2 & 13.68 & 10.33 \\
\hline$n$ & 3 & 2 & 3 & 2 \\
\hline$\theta$ & \multicolumn{2}{|c|}{2.41} & \multicolumn{2}{|c|}{2.37} \\
\hline$s$ & \multicolumn{2}{|c|}{0.59} & \multicolumn{2}{|c|}{0.45} \\
\hline$v$ & \multicolumn{2}{|c|}{24.56} & \multicolumn{2}{|c|}{18.89} \\
\hline$n$ & \multicolumn{2}{|c|}{5} & \multicolumn{2}{|c|}{5} \\
\hline$t(1 \mathrm{a}, 1 \mathrm{~b})$ & \multicolumn{4}{|c|}{-} \\
\hline$t(1 \mathrm{a}, 2 \mathrm{a})$ & \multicolumn{4}{|c|}{$2.63^{*}$} \\
\hline$t(2 \mathrm{a}, 2 \mathrm{~b})$ & \multirow{2}{*}{\multicolumn{4}{|c|}{-}} \\
\hline$t(1 \mathrm{~b}, 2 \mathrm{~b})$ & & & & \\
\hline$t(1,2)$ & \multicolumn{4}{|c|}{0.15} \\
\hline
\end{tabular}

Explanations: $\Theta=$ average, $\mathrm{s}=$ standard deviation, $\mathrm{v}=$ variance, $\mathrm{n}=$ number of cases, $\mathrm{t}=\mathrm{t}$-test for equal means, $*=\mathrm{P}<0,05 ; * *=\mathrm{P}<0,01$ 
The abundance and biomass of brown trout in the natural part of the Oščadnica stream is significantly higher than in the regulated part, with the exception of the regulated part, where the autumn biomass is lower. The average weight does not show any significant differences between the natural and regulated streams; however, the spring values are higher than the autumn values.

\section{Discussion}

There is enough information about the impact of the stream restoration on ichthyofauna (Bovee, 1982, 1986, Booker and Dunbar, 2004, Parasiewicz and Walker, 2007). Most fish species prefer certain combinations of water depths, velocity rates, bedding material and hiding possibilities. Information about the influence of velocity rate and depth of the water on habitat preferences is also sufficient, for example in Macura et al. (2016). However, there is a lack of information on the impact of the environment material, especially on the impact of the stabilisation material. Therefore, the basic aim was to compare the impact of the gabions armouring of the riverbed on the quality of the aquatic habitat. It would be ideal, if the gabion armouring was used for a natural flow for a sufficient length. Such a regulation does not exist in Slovakia, neither in the Czech Republic. Therefore, the Oščadnica stream, where the river channel is armoured by gabions on both sides and the regulation is long enough to reflect the fish habitat preferences, was selected for this study. This regulation is directly linked to the natural stream.

If there would be a significant negative effect of the regulated stream on the ichthyofauna, the research would continue by modelling the quality of the aquatic habitat by the IFIM methodology, specifically the SEFA model. This would allow a partial selection of the impact on the morphological changes in the regulated stream and the impact of the armouring material. Therefore, the reference reach was topographically measured in detail and a hydraulic model for the SEFA program was prepared. The measured results of the abundance and ichthyomass did not confirm any negative state of the restored stream compared to the natural one.

Several authors report that a suitable bioindicator of the environment is brown trout, because it responds sensitively to the changes in flow velocity and depths of the stream (Hooper, 1973; Shirvell and Dungey, 1983; Reiser and Wechse, 1976; Macura, 2016). Alpine bullhead and the stone loach are less sensitive to morphological changes. If we evaluate the trout independently, the abundance and the ichthyomass is higher in the natural stream; except the measurements in June 2015, where the parameters of regulated flow are slightly predominated. If we consider the trout together with minnow, which also sensitively responds to morphological changes, then the parameters will be again higher for the regulated stream, except for the ichthyomass in the measurements from October 2015. For the brown trout, the Wilcoxon signed-rank test has been performed, resulting in $6 \%$ significance of the abundance only. This value indicates the difference between the regulated and the natural stream, but it is not statistically significant. However, it is important to note that the number of measurements is relatively small for a good statistical evaluation. Therefore, the statistical data provided in the article is necessary to comprehend as additional data only. Based on the obtained data it cannot be clearly stated that there is a negative impact of the regulation of the Rajčianka stream as well as influence of the riverbank armouring by gabions is not pronounced. 


\section{Conclusion}

Ambiguous differences in the abundance and ichthyomass values between the regulated and the natural reach confirm that the regulated reach with gabion armouring has no proven (negative or positive) effect on the ichthyofauna, that indicates the biota quality in the stream. Similarly, small differences in zoobenthos were observed. Regarding to the mentioned facts it can be said that there is no significant impact of the gabions on biota in the stream. The aim of the article was to highlight the results of the research and the description of those properties that may affect the use of gabions. The specific properties of this armouring material allow a wide range of uses in the stream regulations and restorations.

Acknowledgements. We thank the Slovak Research and Development Agency for the support of Project no. APVV-16-0253.

\section{REFERENCES}

[1] Aarts, B. G. W., Nienhuis, P. H. (2003): Fish zonation and guilds as the basis for the assessment of ecological integrity of large rivers. - Hydrobiologia 500: 157-178. DOI: 10.1023/A:1024638726162.

[2] Artemiadou, V., Lazaridou, M. (2005): Evaluation Score and Interpretation Index for the Ecological Quality of Running Waters in Central and Northern Hellas. - Environmental Monitoring and Assessment 110: 1-40. DOI: 10.1007/s10661-005-6289-7.

[3] Augustinková, L., Fárek, V., Klepek, J., Krakovská, A., Neruda, M., Ponížilová, I., Strachota, M., Šrejber, J., Unucka, J., Voženílek, V, Winkler, I., Židek, D. (2017): Utilization of the Geoinfomatics and Mathematical Modelling Tools for the Analyses of Importance and Risks of the Historic Water Works. - In: Ivan, I. et al. (eds.) The Rise of Big Spatial Data, Lecture Notes in Geoinformation and Cartography, Springer International Publishing AG, 408 p., ISBN 978-3-319-45123-7.

[4] Avery-Gomm, S., Rosenfeld, J. S., Richardson, J.S., Pearson, M. (2014): Hydrological drought and the role of refugia in an endangered riffle-dwelling fish, Nooksack dace (Rhinichthys cataractae ssp.). - Canadian Journal of Fisheries and Aquatic Sciences 71: 1625-1634. DOI: 10.1139/cjfas-2013-0585.

[5] Bovee, K. D. (1982): A Guide to Stream Habitat Analysis Using the Instream Flow Incremental Methodology. Instream Flow Information Paper 12. FWS /OBS-82 /26. USDI Fish and Wildlife Service, Office of Biology Services: Washington, DC.

[6] Bovee, K. D. (1986): Development and Evaluation of Habitat Suitability Criteria for Use in the Instream Flow Incremental Methodology. Instream Flow Information Paper 21. FWS/OBS-86/7. - USDI Fish and Wildlife Service, Office of Biology Services: Washington, DC.

[7] Booker, D. J., Dunbar, M. J. (2004): Application of physical habitat simulation (PHABSIM) modelling to modified urban river channels. - River Research and Applications 20: 167-183.

[8] Carlson, A. K., Taylor, W. W., Schlee, K. M., Zorn, T.G., Infante, D. M. (2015): Projected impacts of climate change on stream salmonids with implications for resiliencebased management. - Ecology of Freshwater Fish, 26: 190-204. DOI: 10.1111/eff.12267.

[9] Cheek, C. A., Taylor, C. M. (2016): Salinity and geomorphology drive long-term changes to local and regional fish assemblage attributes in the lower Pecos River, Texas. Ecology of Freshwater Fish 25: 340-351. DOI: 10.1111/eff.12214. 
[10] Chovanec, A., Hofer, R., Schiemer, F. (2003): Fish as bioindicators. - In: Markert, B. A., Breure, A. M., Zechmeister, H.G. (eds.) Bioindicators and biomonitors. Elsevier, Amsterdam, 1017 p. (639-675). ISBN: 0-08-044177-7.

[11] Cianfrani, C. M., Mažeika, S., Sullivan, P., Hession, W. C., Watzin, M. C. (2009): Mixed stream channel morphologies: implications for fish community diversity. - Aquatic Conservation: Marine and Freshwater Ecosystems 19: 147-156. DOI: 10.1002/aqc.946.

[12] Cowx, I. G., Welcomme, R. L. (1998): Rehabilitation of Rivers for Fish. - Fishing News Books Ltd., Oxford, 260 p., ISBN 0-85238-247-2.

[13] Döll, P., Zhang, J. (2010). Impact of climate change on freshwater ecosystems: a globalscale analysis of ecologically relevant river flow alterations. - Hydrol. Earth Syst. Sci. 14: 783-799. DOI: 10.5194/hess-14-783-2010.

[14] Friberg, N., Baartrup-Pedersen, A., Pedersen, M. L., Skriver, J. (2005): Application Of Artificial Neural Network Models To Analyse The Relationships Between Gammarus pulex L. (Crustacea, Amphipoda) And River Characteristics. - Environmental Monitoring and Assessment 111: 223-241. DOI: 10.1007/s10661-005-8221-6.

[15] Hooper, D. (1973): Evaluation of the effects of flows on trout stream ecology. - Pacific Gas and Electric Company, Dept. of Engineering Research, Emeryville, California, 97 p.

[16] Keeley, E. R., Campbell, S.O., Kohler, A. E. (2015): Bioenergetic calculations evaluate changes to habitat quality for salmonid fishes in streams treated with salmon carcass analog. - Canadian Journal of Fisheries and Aquatic Sciences 73: 819-831. DOI: 10.1139/cjfas-2015-0265.

[17] Koščo, J., Pekárik, L., Švátora, M. (2010): Reference conditions for fish microhabitat use in foothill streams: A case study on undisrupted Carpathian streams. - River Research and Applications 28: 369-376. DOI: 10.1002/rra.1462.

[18] Leslie, P. H., Davis, D. H. S. (1939): An attempt to determine the absolute number of rats on a given area. - Journal of Animal Ecology 8: 94-113.

[19] Macura, V., Škrinár, A., Kalúz, K., Jalčovíková, M., Škrovinová, M. (2012): Influence of the morphological and hydraulic characteristics of mountain streams on fish habitat suitability curves. - River Research and Applications 28: 1161-1178. DOI: 10.1002/rra.1518.

[20] Macura, V., Štefunková, Z., Škrinár, A. (2016): Determination of the effect of water depth and flow velocity on the quality of an in-stream habitat in terms of climate change. - Advances in Meteorology, Article ID 4560378, 17 p. DOI:10.1155/2016/456037.

[21] Mažeika, S., Sullivan, P., Watzin, M.C., Hession, W.C. (2006): Influence of stream geomorphic condition on fish communities in Vermont, U.S.A. - Freshwater Biology 51: 1811-1826. DOI: 10.1111/j.1365-2427.2006.01616.x.

[22] Murchie, K. J., Hair, K. P., Pullen, C. E., Redpath, T. D., Stephens, H. R., Cooke, S. J. (2008): Fish response to fluctuating flow in regulated rivers: research methods, effects and opportunities. - River Research and Management 24:197-217. DOI: 10.1002/rra. 1058

[23] Palmer, M. A., Menninger, H. L., Bernhardt, E. (2010): River restoration, habitat heterogeneity and biodiversity: a failure of theory or practice? - Freshwater Biology 55: 205-222. DOI: 10.1111/j.1365-2427.2009.02372.x.

[24] Parasiewicz, P., Walker, J. D. (2007): Comparison of MesoHABSIM with two microhabitat models (PHABSIM and HARPHA). - River Research and Applications 23: 904-923.

[25] Pastuchová, Z., Lehotský, M., Grešková, A. (2008): Influence of morphohydraulic habitat structure on invertebrate communities (Ephemeroptera, Plecoptera and Trichoptera). Biologia 63: 720-729.

[26] Pont, D., Hugueny, B., Beier, U., Goffaux, D., Melcher, A., Noble, R., Rogers, C., Roset, N., Schmutz, S. (2006): Assessing river biotic condition at a continental scale: a European approach using functional metrics and fish assemblages. - Journal of Applied Ecology 43: 70-80. DOI: 10.1111/j.1365-2664.2005.01126.x. 
[27] Reiser, D. W., Wesche, T. A. (1976): Determination of physical and hydraulic preferences of brown and brook trout in the selection of spawning locations. - University of Wyoming,Water Resources Research Institute, Water Resources Series 64, 224 p.

[28] Roni, P., Beechie, T., Pess, G., Hanson, K. (2014): Wood placement in river restoration: fact, fiction, and future direction. - Canadian Journal of Fisheries and Aquatic Sciences 72: 466-478. DOI: 10.1139/cjfas-2014-0344.

[29] Schlosser, I. J. (1987): A conceptual framework for fish communities in small warmwater streams. - In: Matthews, W. J., Heins, D. J. (eds.) Community and evolutionary ecology of North American stream fishes. University of Oklahoma Press, Norman.

[30] Schlosser, I. J. (1990): Environmental variation, life history attributes, and community structure in stream fishes: implications for environmental management assessment. Environmental Management 14: 621-628. DOI: 10.1007/BF02394713.

[31] Schmutz, S., Jungwirth, M. (1999): Fish as indicators for large river connectivity: The Danube andits tributaries. - Large Rivers 11: 329 - 348. DOI: 10.1127/lr/11/1999/329.

[32] Shirvell, C. S., Dungey, R. G. (1983): Microhabitats chosen by brown trout for feeding and spawning in rivers. - Transactions of the American Fisheries Society 112: 355-367.

[33] Snelder, T. H., Lamouroux, N. (2010): Co-variation of fish assemblages, flow regimes and other habitat factors in French rivers. - Freshwater Biology 55: 881-892. DOI: 10.1111/j.1365-2427.2009.02320.x.

[34] Welcomme, R. L., Winemiller, K. O., Cowx, I. G. (2006): Fish environmental guilds as a tool for assessment of ecological condition of rivers. - River Research and Applications 22: 377-396. DOI: 10.1002/rra.914.

[35] Zhang, H., Wang, C. Y., Wu, J. M., Du, H., Wei, Q. W., Kang, M. (2016): Physical habitat assessment of a remaining high-biodiversity reach of the upper Yangtze river, China. - Applied Ecology and Environmental Research 14: 129-143. DOI: http://dx.doi.org/10.15666/aeer/1401_129143. 